\title{
Urban Expansion and Its Impact on the Livelihood of Peripheral Farming Communities: The Case of Assosa Town, Benishangul Gumuz Region, Ethiopia
}

\author{
Tadele Tesfaye Labiso \\ Department of Geography and Environmental Studies, College of Social Science and \\ Humanities, Wolayta Soddo University, Ethiopia \\ E-mail: tadetesfa91@gmail.com
}

Received: Nov. 16, 2020 Accepted: Dec. 20, 2020 Published: Dec. 23, 2020

doi:10.5296/bmh.v8i2.18109 URL: http://dx.doi.org/10.5296/bmh.v8i2.18109

\begin{abstract}
Assosa town's expansion program which had been experiencing a horizontal expansion starting from its historical expansion pattern currently implemented via expropriating peripheral land holders of earlier rural dwellers by solely decision of town administration and the investigation randomly targeted to per-urban areas from four peripheral kebeles surrounding of town. Therefore, the objective of this study is to assess Urban Expansion and its Impact on Peripheral Farming Communities: The Case of Assosa town, BGR, Ethiopia Thus the study investigated the impact of urban expansion on the peripheral community livelihood in case of Assosa town. Questionnaire, survey, focus group discussion and key informants interviews were tools of data collection from 160 sampled households living in sampled kebeles via systematic random sampling technique and judgmental technique for FGD and interview. The results of the study indicated that there is infrastructural improvement, socio economic growth, rapid population growth and also socio-economic problems related to urban expansion in studied area. There is great spatial and temporal land use land cover modification more towards to build up land uses. The livelihood condition of per-urban community changed to non-agricultural form but there are policy and strategy gaps of expropriating, compensating for affected community in ground implementation. Landholder expropriated should be recompensed for equal socio-economic beneficially from urbanization and further skill-oriented training for new livelihood strategy and also accessing credit and rehabilitating strategy were recommended for affected community livelihood.
\end{abstract}

Keywords: per urban, expropriation, livelihood, peripheral community 


\section{Background of the Study}

Urban expansion as a dynamic process of land use change is a complicated social/economic phenomenon. It may be linked with details related to topography, transportation, land use, social structure and economic type, but it is generally related to demography and economy in a city (LinLi et al., 2003).

Urbanization, the process of urban expansion may involve both horizontal and vertical expansion of the physical structure of urban areas. It can result in loss of agricultural land, natural beauties, range lands, parks and sceneries (Melesse, 2004). According to the World Urbanization Prospects reported by the United Nations (UN, 2012), from 1965 to 2010, the global population increased from 3.3 billion to 6.9 billion, and the total amount of population will exceed 9.3 billion by 2050 . Along with the population growth, more and more people chose to live in urban areas. The percentage of the world's population residing in urban areas increased from $35.5 \%$ in 1965 to $51.6 \%$ in 2010 and this number will reach at $67 \%$ in 2015 (UN, 2012).

Ethiopia is one of the least urbanized countries in the world. It has only $16 \%$ of its population living in urban centers. However, given the $2.73 \%$ total annual population growth rate, high rate of in-migration to towns, and increase in the number of urban centers, the rate of urbanization is increasing at a rate of $4.4 \%$ (MoFED, 2006).

Furthermore, the country's urban population is expected to grow on average by $3.98 \%$ and by 2050 ; about $42.1 \%$ of the total population is expected to be inhabited in urban centers (UN HABITAT, 2007).

Urban environmental problems become worse in urban areas in the case of Ethiopia being one of the impoverished African countries. Because of the many interrelated urban environmental problems none of the Ethiopian cities has the ability to continue sustainable urban development (World Bank, 2000).

Assosa is one of towns among those rapidly expanded urban centers in Ethiopia terms of population and physical size. The population size of the town was estimated is 80,461 . The total area that is covered with the current topographic map of the town is estimated to be $10.5 \mathrm{sq} \mathrm{Km}$ (CSA, 2010).

Assosa is situated near to west wellega zone with a distance of $124 \mathrm{Km}$. Due to its proximity to wellega large numbers of people come to the area for residence and investments. Moreover, easy access to infrastructures such as roads and electricity has exhibited an important role in the attraction of private investment in and around the town (BoFED, 2010). Hence, large tracts of land have been expropriated from local farming community and have been utilized for private investments and urban land use.

Generally, urban expansion is one of the basic problems that affect the living standard and food security of many agrarian economy peoples in developing countries. This invasion process leads to the loss of agricultural farm lands, grazing land, bare land and reduction of crops/food productivity (Fekadu, 2015). 


\section{Al Macrothink}

Business and Management Horizons

ISSN 2326-0297

2020, Vol. 8, No. 2

Urbanization in Ethiopia also exposed to a number of challenges because of that, unplanned settlement, and population pressure and slums seen in most cities and towns of Ethiopia. For example, Addis Ababa is one of which face such situation that caused from historical background of city's settlement first existence with ineffective urban planning due to the problem of lack of legal land affordability to individual people, city faced with a problem of housing in addis ababa during Derg regime.

According to Firew (2010), urban expansion and urban growth is cyclic phenomenon that leads to dislocating rural agricultural community. Even well-planned resettlement of community has adverse effects on the livelihood of community during and after community displaced affected. In case of our country context, a number of researches have been conducted in cities and towns entitled of impacts of urban expansion on sub-urban community livelihoods. For instance, Firew (2010) conducted a research which assessed the horizontal urban expansion and peripheral community livelihoods with great attention of examining impacts of urbanization well.

Therefore, this study Assess the impact of urban expansion on the livelihood of per urban communities of Assosa Town, BGR, Ethiopia.

\subsection{Objectives of the Study}

The general objective of this study is to assess socio economic impact of urban expansion on the livelihood of peripheral farming community of Assosa town.

The specific objectives of this study are:

$>$ To evaluate the implication of urban expansion on the social environment in the study area

To examine consequences of urban expansion on the economic environment in the study area

To identify livelihood change of peripheral households related to urban expansion

\subsection{Significance of the Study}

Assosa is one of towns expanding to edge of urban settlement and no more study has carried out there. For instance, there is a little study done concerned to impact assessment of urban expansion on community living condition. But, this study can narrow the knowledge gap through identifying positive as well as negative consequence and recommend possible solution for affected groups.

The research finding can also contribute certainly legal form but informal urban housing via providing assessed research result from community of suburban areas which means their perception and livelihood implication on them. As a whole, the used to develop knowledge on an implication of urban expansion towards peripheral community and can be the primary document for urban municipality in case study. 


\section{Macrothink}

\subsection{Map of the Study Area}

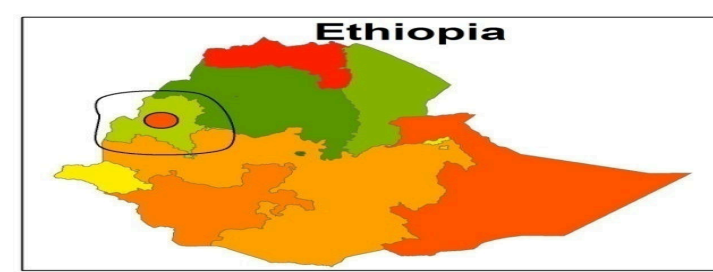

Benishangul-Gumuz Region

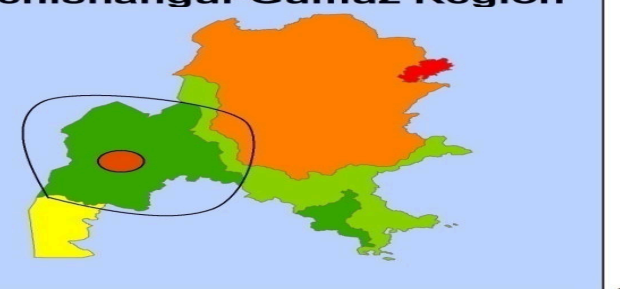

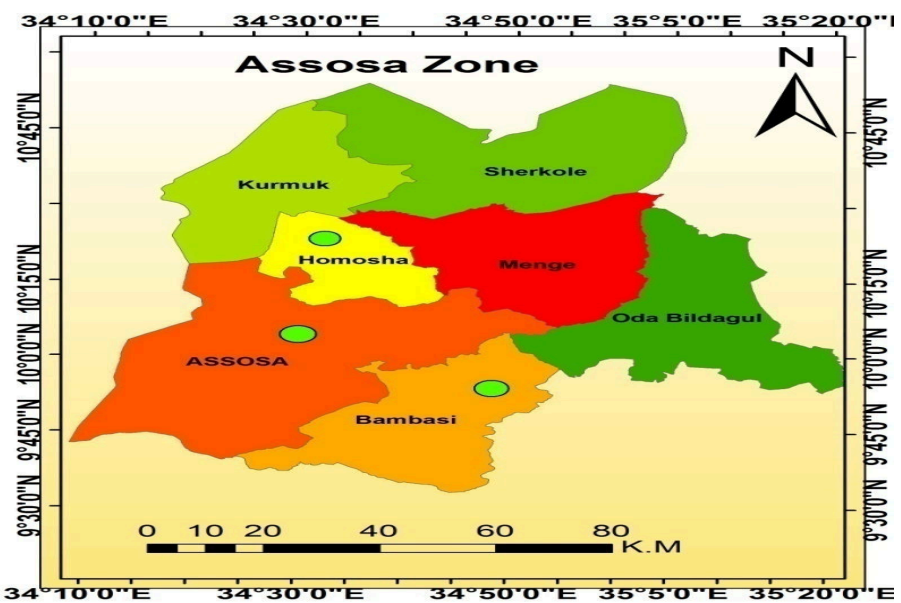

Figure 1. Map of the study area

\section{Research Approach}

In this research, the descriptive research design was employed. This is due to the fact that the study primarily focused on assessing the impact of urban expansion on the peripheral community livelihoods. So, it dealt with detail identification on urban expansion condition previously and during the study time.

This feature description led as the research has a qualitative nature. Therefore, the study had a quantitative character. In general, the descriptive design of research incorporated with mixed qualitative and quantitative research via hybrid interpretation of data in both natures side by side.

\subsection{Source of Data}

In order to achieve the main objective of the research that is assessed impact of urbanization towards to the peripheral community livelihoods, the researcher used both primary and secondary data sources since it was vital for the study result.

Most of primary data sources for the study collected through implementation of tools listed under instruments of data collection below. On other hand, secondary data sources basically required from all available reports of offices in town administration, other related published books, journals and other written or documented data also used to examine issues under investigation.

\subsection{Sampling Techniques and Sample Size Determination}

Collecting data from all population included in the study was too tiresome due to its great time, effort and financial requirement. Then selection of sample for the whole was needed. To balance size of representative population and reduce problem of sampling error, both of 
probability and non-probability sampling techniques were used in respective of targeted population required for relevant information to issue investigation.

Since issues of this investigation entitled with assessing impact of urban expansion on peripheral community livelihood concerned only per-urban areas of Assosa town. Geographically, Kebele framed to select sample strata focused only to the four rural-urban linked areas such as; amba 05, amba 08, amba 09, amba07 those recently added to an administration. Due to this reason, the researcher took sample kebeles and respondents from rural-urban transition of urban or home of households expropriated for expansion purposively or judged as geographical scope of the study.

So, the researcher interviewed elder household heads of area and experts of municipality. Similarly, FGD samples were another participant for discussion on issues studied. Representative samples from the households of selected kebeles were based on scientific formula at required degree of confidence. Therefore, representative sample of these households have been calculated based on formula for sample size determination and for finite population.

According to (Dirribsa \& Tassew, 2015). The formula is given as: $n=$ z2.p.q.Ne 2. $N-1+z$ 2.P. $q=1.962 * 0.5 * 0.5 * 44100.082 * 4410-1+1.962 * 0.5 * 0.5=3.8416 * 0.25 * 44100.0064 *$ $4409+3.8416 * 0.25=4235.36429 .178=160$.

Where $\mathrm{n}=$ required sample size $=145, \mathrm{~N}=$ Population $=4,410, \mathrm{Z}=$ Confidence interval at $95 \%$ which is $1.96, \mathrm{e}=8 \%, \mathrm{P}=0.5, \mathrm{q}=0.5, \mathrm{Z}=95 \%$ confidence interval under normal curve 1.95. The samples of respondent are taken from each kebeles on the basis of the formula given above). $\mathrm{e}=$ acceptable error term $(0.08), \mathrm{P}$ and $\mathrm{q}$ are estimates of the proportion of population to be sampled and $\mathrm{N}=$ total population.

Additionally, there were 8 key informants from those purposively targeted elders and experts and 12 FGD participants out of the elders and experts. Generally, sampled household heads for study are the summation of sampled household heads for questionnaire, key informants interview and FGD participants.

\section{Data Collection Tools}

As a tool to generate the most relevant information for the study, the researcher implemented tools like; questionnaire, in depth interview with key informants, FGD and personal observation during data collection in accordance of time and place required.

\subsection{Questionnaire}

The researcher employed questionnaire containing closed ended and open-ended question to gather decisive data in case of qualitative and quantitative analysis of results on, current status of urban growth, livelihood changes to per-urban households, impact of urbanization and the constraints relating expansion respectively.

\subsection{Key Informants Interview}

Interview with key informants additionally carried out with samples selected purposively 


\section{Mll Macrothink}

Business and Management Horizons

ISSN 2326-0297

2020, Vol. 8, No. 2

from different management hierarchy official experts and randomly selected elder representative from community in range of adverse impacts of urbanization.

\subsection{Focus Group Discussion (FGD)}

Focus group discussion (FGD) of 5-6 participants selected from each of sampled kebeles particularly affected household heads and experts of town municipal judged as a sample. This tool more or less applied on detail discussion of critical issues investigated based on reflection of open-ended questions by a researcher as chairperson of discussion.

\subsection{Data Analysis Techniques}

However, the study has both qualitative and quantitative approach of analysis, prior of any data analyzing techniques data from survey questionnaire was collected, recorded, coded and filled into computer as input of processing and analyzing in SPSS software. Primary data concerned to livelihood condition, livelihood change, strategy gaps and other related data analyzed through descriptive techniques.

To make question survey result strong, FGD and interview results analyzed via narrating responses by statement. In addition to this, more of questions regarding to urban expansion impact assessment of livelihood i.e., different assets of community before and after an event numerically collected and analyzed by using statistical tool specifically repeated measures or dependent t-test of significance. Then, result of analysis in SPSS software presented inform of tables, pie chart and bar graphs followed by brief discussion based on result representing facts of the studied area and previous studies.

\section{Result and Discussion}

The data collected from the household sample size and the interviewed officials in the study area of Assosa town, Impact of Urban Expansion on the surrounding environment is presented and discussed in this chapter. These include exploring the environmental consequences of urban expansion. This chapter also identifies social effects of urban expansion in the town. Finally, it identifies the economic consequences of urban expansion in the study area.

\subsection{Demographic Profiles of the Sample Respondents}

Demographic profiles of the respondents in the sample size are discussed here based on the data obtained from both sample households. Out of the total respondents that have been interviewed during the survey $69 \%$ percent and 31 percent were male and female respectively. Table 1 below demonstrates the percentage of the respondents' sex. 
Table 1. Sexes of the respondents

\begin{tabular}{lll}
\hline Options & Number of Sex Respondents & Value in Percentage \\
\hline Male & 110 & 69 \\
Female & 50 & 31 \\
Total & 160 & 100 \\
\hline
\end{tabular}

Source: Field Survey, 2019.

From the figure, the majority of the respondents were male. This is due to the fact that during the data collection most of the respondents found were men. To come with the age of the respondents, 27.9 percent were less than 30 years old, 52.9 percent were 30-60 years. 19.3 percent were above 60 years. This implies that the majority of the respondents were aged 30-60 (52.9 percent) and the smallest numbers of the respondents were aged above 60 (19.3 percent). This shows that majority of the households were in the active age group who feel the problem of urban expansion on the surrounding Environment and this information clearly exposed in the Table 2 below.

Table 2. Ages of the respondents

\begin{tabular}{llll}
\hline No & Age category & Frequency & Percentage \\
\hline 1 & $<30$ & 39 & 24.3 \\
2 & $30-60$ & 94 & 58.75 \\
3 & $>60$ & 27 & 16.75 \\
4 & & 100 & 100 \\
\hline
\end{tabular}

Source: field Survey, 2019.

With reference to the educational level of the respondents, 42 percent were illiterate, 16 percent were those completed their elementary and intermediate level, 18 percent completed secondary school and 24 percent earned certificate and above from Colleges and Universities. This indicates that most of the responds were able to read and write that made for the possible to have an understanding of how urban expansion affected their different environments.

\subsection{Marital Status of the Respondents}

As it shown on (Table 3), the majority of the respondents $102(64 \%)$ are married followed by single, divorced and widowed with 25 (17.2\%), 14 (9.7\%) and 19 (13.1\%) respectively. Hence, the respondents could give their answer from their experience of administering family and caring responsibility.

\subsection{Urban Expansion Impacts on Farmers 'Economic Environment'}

According to (Table 3), the sample households of respondents, 1 (0.7\%), 8 (5.5\%), 29 (20\%), $64(44.1 \%)$ and $43(29.7 \%)$ reported that these households used to earn total annual income of 


\section{Macrothink}

41-50 quintal, 31-40 quintal, 21-30 quintal, 11-20 quintal and below 10quintals respectively before urban expansion. After urban expansion, they reported that to have earned $0(0 \%), 1(0.7 \%), 10(6.9 \%), 51(35.2 \%)$ and 83 (57.2\%) for 41-50 quintal, 31-40 quintal, 21-30 quintal, 11-20 quintal and below 10 quintals respectively. This indicates that annual production/ income decreased after urban expansion in the study area.

This can be seen from the following table that number of respondents who produced 41-50 quintal decreased from $0.7 \%$ to $0 \%, 31-40$ quintal from $5.5 \%$ to $0.7 \%, 21-30$ quintal from $20 \%$ to $6.9 \%$ and $11-20$ quintal from $44.1 \%$ to $35.2 \%$. But number of respondents who produce less than 10quintals increased their income from $29.7 \%$ to $57.2 \%$. This is to mean that, the majority of the population produces fewer amounts less amount of quintals after urban expansion. This corresponds to the study by (Dayong, 2004) as displacing farmers cause to reduce the amount of production.

Table 3. Annual income before and after Urban Expansion in quintal and percent in 2006-2016

\begin{tabular}{llllll}
\hline Before urban expansion & \multicolumn{3}{l}{ After urban expansion } \\
\hline Quintal & $\begin{array}{l}\text { Number of } \\
\text { respondents }\end{array}$ & Percent & Quintal & $\begin{array}{l}\text { Number of } \\
\text { respondents }\end{array}$ & Percent \\
\hline Below 10 & 58 & 29.7 & Below 10 & 98 & 57.2 \\
From 11-20 & 64 & 44.1 & From 11-20 & 51 & 35.2 \\
From 21-30 & 29 & 20.0 & From 21-30 & 10 & 6.9 \\
From 31-40 & 8 & 5.5 & From 31-40 & 1 & 0.7 \\
From 41-50 & 1 & 0.7 & From 41-50 & 0 & 0 \\
Total & $\mathbf{1 6 0}$ & $\mathbf{1 0 0}$ & Total & $\mathbf{1 6 0}$ & $\mathbf{1 0 0}$ \\
\hline
\end{tabular}

Source: Own survey, 2019.

\subsection{Benefits Farmers Gained as a Result of their Participation}

As (Table 4) shows us, about $44.8 \%$ of a farming community claimed that they had not participate in a benefit packages and compensation decision making processes. On the other hand, about $55.2 \%$ of the farmers whose livelihood was affected agreed that they had participated in the program through different participation benefit packages. 


\section{Macrothink}

Table 4. Benefits farmers gained from participation

\begin{tabular}{lll}
\hline Participation benefit & Number of respondents & Percent \\
\hline Raised own interest & 28 & 19.3 \\
Expressed own opinion & 12 & 8.3 \\
Created access to benefit packages & 29 & 9.7 \\
All above benefit & 26 & 17.9 \\
Total & 80 & 55.2 \\
Missing System & 65 & 44.8 \\
Total & $\mathbf{1 6 0}$ & $\mathbf{1 0 0 . 0}$ \\
\hline
\end{tabular}

Source: Own survey, 2019.

\subsection{The Impact of Urban Expansion on the Land holding of Farming Community}

As we can see from the (Table 6) below, $102(70.3 \%)$ said they lose their land while $43(29.7 \%)$ said they did not lose their land. This indicates that majority of farmers loosed their land. So, the expansion has an impact on household livelihood.

Table 5. The impact of urban expansion on the land holding of farming community

\begin{tabular}{lll}
\hline Lose of land & Number of respondents & Percent \\
\hline Yes & 1117 & 70.3 \\
No & 43 & 29.7 \\
Total & $\mathbf{1 6 0}$ & $\mathbf{1 0 0 . 0}$ \\
\hline
\end{tabular}

Source: Own survey, 2019.

\subsection{Type of Land Loss due to Urban Expansion}

As it is indicated in (Table 6), the respondents reacted that most of the respondents $70.3 \%$ loss of land which is the impact of urban expansion for farmers who are dependent on their land for means of earning their livelihood in one case or the other. From this, grass land vacated high percent which is $31 \%$ followed by residential lands with $15.9 \%$, agricultural land and all type of lands respondents who loss with $11.7 \%$ for each.

Table 6. Type of land loss due to urban expansion

\begin{tabular}{lll}
\hline Type of land loss due to urban expansion & Number of respondents & Percent \\
\hline Agricultural land & 60 & 11.7 \\
Residential land & 23 & 15.9 \\
Grass land & 17 & 31.0 \\
All type of land (agricultural, residential and grass lands) & 17 & 11.7 \\
Total & 102 & 70.3 \\
Total & $\mathbf{1 6 0}$ & $\mathbf{1 0 0 . 0}$ \\
\hline
\end{tabular}

Source: Own survey, 2019. 


\subsection{Compensation Given Instead of the Land Vacated}

Most of the respondents get compensation for the land vacated from them with 101 (69.7\%) of the total. While $8(5.5 \%)$ claims, they did not get any kind of compensation. This might be due to the regional government policy that encourages local communities to give their land for infrastructure development such as road without compensation.

Table 7. Compensation given for the land vacated

\begin{tabular}{lll}
\hline compensation & Number of respondents & Percent \\
\cline { 2 - 3 } Yes & 116 & 69.7 \\
No & 8 & 5.5 \\
Total & 110 & 75.9 \\
Missing System & 36 & 24.8 \\
Total & $\mathbf{1 6 0}$ & $\mathbf{1 0 0 . 0}$ \\
\hline
\end{tabular}

Source: Own survey, 2019.

\section{Kinds of Compensation Paid}

Compensation paid for land vacated was 61 (42.1\%) money, 25 (17.2\%) housing plots, 2 (1.4). This implies, unless required care and training given for those displaced farmers, it might be difficult to liquid money asset for lifelong livelihood or shift from the work they adopted which is farming to other income generating activity.

Table 8. Kinds of compensation paid

\begin{tabular}{lll}
\hline kind of compensation & Number of respondents & Percent \\
\hline Compensation (money) & 76 & 52.4 \\
Housing plots & 40 & 17.2 \\
Total & 101 & 69.7 \\
Missing System & 44 & 30.3 \\
Total & $\mathbf{1 6 0}$ & $\mathbf{1 0 0 . 0}$ \\
\hline
\end{tabular}

Source: Own survey, 2019.

\subsection{Levels of Farmers'Satisfaction with Compensation Served}

In a relation with this, these households also had been asked whether they had been satisfied or not with the compensation given to them and benefits they had gained as a result of urban expansion towards their vicinity. As we can read from (Table 9) below, 62.1\% of the households had responded as they had not satisfied with the compensation they had been given and benefits these households whose livelihood had been affected cause of urban expansion had gained. $37.9 \%$ were satisfied. Most of the sampled households were not satisfied with 
compensation obtained. Their reason for the dissatisfaction is that the compensation provided were not enough to sustain their livelihood and replace their income that was previously earned from agricultural land.

Table 9. The recipients' satisfaction condition towards a served compensation

\begin{tabular}{lll}
\hline farmers' satisfaction with compensation served & Number of respondents & Percent \\
\hline Satisfied & 55 & 37.9 \\
Dissatisfied & 105 & 62.1 \\
Total & $\mathbf{1 6 0}$ & $\mathbf{1 0 0}$ \\
\hline
\end{tabular}

Source: Own survey, 2019.

\subsection{Impact of Urban Expansion on Infrastructure of households}

As we can see from the following (Table 10) below, 33 out of 145 respondents answered that they got all infrastructures followed by clinic and health institution with 25 , school with 18 , water supply with 17 , credit service with 16 , recreation with 15 , road with 11 , electricity with 6 and market accessibility with 4 respondents respectively and at least 33 (23\%) respondents answered as they got all infrastructures. Therefore, from this we can concluded that urban expansion has positive impact on peripheral farming community in terms of physical capital which is measured in terms of infrastructure in the study area.

Table 10. Impact of urban expansion on Infrastructure of households

\begin{tabular}{lll}
\hline Types of infrastructures & Frequency & Percent \\
\hline Road & 26 & 7.6 \\
Electricity & 6 & 4.1 \\
Water supply & 17 & 11.7 \\
School & 18 & 12.4 \\
Clinic \& other health institution & 25 & 17.2 \\
Credit service & 16 & 11.0 \\
Recreation & 15 & 10.3 \\
Market & 4 & 2.8 \\
All types of infrastructures & 33 & 22.8 \\
Total & 160 & 100.0 \\
\hline
\end{tabular}

Source: Own survey, 2019.

\subsection{Impact of Urban Expansion on the Peripheral Communities 'Assets}

Livelihood is the means to gain different currency as well as other basic and luxury material. This entire requirement needs source of income from what they stored in different form of 
asset as ever livelihood and income base from varied job opportunity. Assets are stocks of capital considered as basic building blocks upon which households depend to generate the means of survival which includes natural, physical, human, financial and social capital (Ellis, 2000 , p. 31). For this livelihood assessment, natural, physical and social asset of the peripheral community has been examined as discussed below. But, financial assets like farm, non-farm and annual incomes and expenditures haven't used since households might not remind that of before expansion as well.

\subsection{Declining of Agricultural Land and Other Assets}

The survey result showed that average land holding of sample household is the lowest to survive their life. Hence, some households particularly, youth are employed themselves as casual daily laborer and low-income earning activities to compliment their agricultural income. Farmers who posses relatively enough capital usually rent agricultural land from other nearby area in order to secure their livelihood. However, currently the cost of land is rising which cannot be afforded by most of the poor household. Other also engages in traditional share cropping practice.

\subsection{Impact on Land Tenure}

Evidences from key informants show that, there is serious land tenure insecurity among most farmers in peri-urban areas of Assosa town. Due to this, particularly farmers who possess farm land and located near to the town, sell their agricultural land with low price with an expectation that their land is likely expropriated by municipality. Hence, many farmers become landlessness and engage in low income earning activities mostly in daily labour.

\subsection{Respondents' Suggestions in Improving Urban Expansion Strategies}

In developing countries both the causes and consequences of urban expansion are mixed involving both positive and negative aspects. Ethiopia, being one of the developing countries, is not exceptional to the urban expansion phenomena that has occurred in other developing countries and Assosa, the capital city of benishangul gumuz regional state shows both the negative and positive consequences of urban expansion, but the respondents for this study has been forwarded on how they suggest that urban expansion, which means development in terms of its importance, can be managed in order not to affect the natural environment, Social environment and economic environment of the population being affected by urban expansion.

The respondents stated as indicated in Table 11 that legislation system (27\%) should be put in place in order prevent any illegal land acquisition and better land use planning $(20 \%)$ that will help in the proper zoning of the different uses of the urban land. Participatory land management $(19.3 \%)$ has been put as one important solution to the unplanned urban expansion in the city by the respondents; they have mentioned that community participation is very important in the implementation of the land use policies in the city. The respondents mentioned that Political commitment $(13.6 \%)$ is very necessary in solving problems related with urban expansion and lastly respondents indicated that proper land administration system (7.9) is paramount to getting solution of the problems prevailing currently in the area where 
urban expansion is occurring. The table below indicates major suggestions of respondents to improving urban expansion related issues.

Table 11. Respondents' suggestions to improve urban expansion related problems

\begin{tabular}{llll}
\hline No & options & Number of Respondents & Value in Percentage (\%) \\
\hline 1 & Legislation system & 38 & 27 \\
2 & Better land use planning & 43 & 20 \\
3 & Participatory land management & 32 & 19.3 \\
4 & Political commitment & 19 & 13.6 \\
5 & Proper land administration system & 11 & 7.9 \\
6 & total & 160 & 100 \\
\hline
\end{tabular}

Source: field survey, 2019.

\section{Conclusion}

Urban expansion, among other urban related problems, has currently become a concern of local Governments in developing countries. In the study area 90.7 percent of the respondents supported the existence of fast-growing urban expansion.

The major underlying causes of the environmental problems in the study area due to poor and unplanned urban expansion are poor municipal services (37.9\%), lack of committed leadership (28.6\%), lack of environmental awareness $(22.9 \%)$ and poor residential waste management $(10.6 \%)$.

The biggest social consequence of urban expansion is high competition for jobs and the least is loss of traditional way of life (10\%). The economic consequences of urban expansion are lack of basic services and high cost of living among others.

Sustainable urban expansion needs the development of proper legislation that can serve as a ruling material in urban land management issues, better land use planning, participatory land management, political commitment and proper land administration system by the city municipality of Assosa.

Factors like land size, age, sex and education level has critical role for the families living in peri urbanarea of Assosa town in determining their livelihood diversification and to cope-up an impact of rapid expansion of the town.

Family's with relatively high land size is made little livelihood diversification relative to low land holdings and non - farm land. Old age people were the least one in terms of changing and diversifying their livelihood. Although high numbers of industries located and operated in the area, they did not capable to absorb local communities. This is because local people lack skill and education that required by these industries. 


\section{Recommendation}

The finding of this research study has shown clearly that there is poor and unplanned urban expansion system and much more commitment is needed to deal with inherent weaknesses that have been identified.

* Therefore, this study suggests the following recommendations to put forward for future success in the urban expansion related matters

$>$ Urban planning authorities and town planners should think about the future growth of the town and should understand the consequence of unbalanced physical urban growth and, public service and infrastructure supply.

$>$ The urban expansion program implemented so far indicated that the communities were not given awareness and participated in planning and implementation of the process.

$>$ The municipality should allocate adequate budget for from their annual revenue to provide infrastructural services that that are badly required by the newly settled communities in order not to exacerbate the existing environmental situation that is currently prevailing in the urban expansion affected area of the town.

$>$ Therefore, to ensure sustainable urban development, government should make careful planning prior to displacement.

$>$ Appropriate compensation package that could replace the resource base of evicted households should be pursued. Before displacement, livelihood initiative like skill development, training and awareness should be given for families on pri-urban areas to enhance them diversify their livelihood.

$>$ An economy of most peripheral community before expansion was agricultural activities though more or less they shifted to other due to the problems suggested in previous sub topics. Since most community reflecting inability to adopt urban livelihood, stakeholder's subsidy to participated on own business via skill-oriented training for new livelihood strategy and exemplary usage of finance strategy is recommended.

Actually expansion of town towards to per-urban area modified community livelihood strategy to non-farm though the only livelihood strategy more uneducated community engaged for a long period of time was farming sector. Thus, livestock as income source of affected community should be replaced by research based few livestock reproduction techniques.

\section{Acknowledgement}

Above all I would like to thank the Almighty God for his unreserved gift. First and foremost, I want to express my gratitude to research participants including my wife Tinsae Abraham Bassa whom I am duly bound to express my gratitude. They devoted their precious time and energy to comment on and improve the progress of the study since its initiation. Without their guidance and professional expertise, the completion of this work would not have been possible. I am indebted to Assosa University research and community service directorate and large number of 
individuals for their encouragement and help while conducting this study.

\section{References}

Abdissa, F. (2005). Urban Expansion and the Livelihood of the Peri-Urban Agricultural Community. A Master's Thesis. Institution of Regional and Local Development, Addis Ababa University.

Alemu, A., \& Amare, G. (2015). Urban Expansion and Farmers' Perceptions in Axum Town. Ethiopia: Mekelle University.

Allen, A. (2003). Environmental Planning and Management of the Per-urban Interface: Perspectives on an Emerging Field. Environment and Urbanization, 15(1), 135147. https://doi.org/10.1177/095624780301500103

Ayele, K. F. (2011). Assessment of Soil Erosion Risk in the Holeta Watershed. Central Oromiya, Ethiopia: Addis Ababa University, M Sc thesis.

Balchin, I. D., \& Chen, J. (2000). Urban Economics: A Global Perspective. Great Britain Wales: Palgrave. https://doi.org/10.1007/978-1-137-06223-9

Dayong, N. (2004). Several Acute Issues in China's Urban Planning. Retrieved December 20, 2014, from http://www. Lincoln instedu/pubs/pub-detail aspid 872

Fekadu, T. (2015). Urban Expansion and Its Effects on Peripheral Farming Community. Hossana Ethiopia.

Feyera, A. (2005). Urban Expansion and Livelihood of the Per-urban Agricultural Community: The case of Finfine. MA Thesis: Addis Ababa University.

Firew, B. (2010). The Impact of Horizontal Urban Expansion on Sub-Urban Agricultural Community Livelihood: The Case of Tabor Sub-City. Hawassa city, SNNPRS, Ethiopia.MA Thesis unpublished; Addis Ababa University.

Kedir, A. (2010). Urban expansion and the neighbourhoods: The Case of Bishoftu Town. East Shewa Zone, Oromia Regional State. Addis Ababa University.

Kothari, C. R. (1995). Research Methodology, Methods and Techniques (7th ed.). New Delhi, India.

Nebiyu, B. (2000). The Impacts of Development Induced Urban Settlement Schemes on Relocated Households. A Master's Thesis. Institute of Regional and Local Development, Addis Ababa University.

Simon, D, (2008). Urban Environments: Issues on the Per-Urban Fringe. Annual. Review of Environment and Resources, 33, 167-185. https://doi.org/10.1146/annurev.environ.33.021407.093240

Tamirat, M. (2016). Horizontal Urban Expansion and Livelihood Adjustment Problem Among Ex-Farmers in the Kebeles Surrounding Jimma Town: The Case of Derba Kebele Jimma University, Ethiopia. European Scientific Journal, 12(14). 


\section{Macrothink}

Business and Management Horizons

ISSN 2326-0297

2020, Vol. 8, No. 2

https://doi.org/10.19044/esj.2016.v12n14p308

UN, H. (2007). State of the World Cities 2010/2011: Bridging the Urban Divide. United Nations Human Settlements Programme. Nairobi, Kenya. https://doi.org/10.4324/9781849774864

\section{Copyrights}

Copyright for this article is retained by the author(s), with first publication rights granted to the journal.

This is an open-access article distributed under the terms and conditions of the Creative Commons Attribution license (http://creativecommons.org/licenses/by/4.0/). 